\title{
Improving Early Childhood Education Management through Problem Identification of Institutions
}

\author{
Upik Elok Endang Rasmani ${ }^{1 凶}$, Warananingtyas Palupi², Jumiatmoko³ ${ }^{3}$ Nurul Shofiatin \\ Zuhro ${ }^{4}$, Anjar Fitrianingtyas ${ }^{5}$ \\ Pendidikan Guru Pendidikan Anak Usia Dini, Universitas Sebelas Maret $(1,2,3,4,5)$ \\ DOI: $\underline{10.31004 / \text { obsesi.v6i1.888 }}$
}

\begin{abstract}
The success of managing early childhood education institutions is determined by management aspects such as curriculum, infrastructure, marketing, students, supervision and educators. One of the most important management is management that regulates education personnel because this management determines how educators provide facilities to develop children's abilities so that they can achieve the expected educational goals. This study aims to improve PAUD (Early Childhood Education) Management by identifying institutional problems. This study used a qualitative descriptive research model. The research sample was teachers in Kindergarten AULIA Surakarta. The results showed that the observation, attention, communication, personality of the teacher and the child was good and the teacher always conducted consultations on children's problems. It showed that the average AULIA Surakarta kindergarten teacher had done their job well.
\end{abstract}

Keywords: identification; ece management; institutions quality

\begin{abstract}
Abstrak
Keberhasilan pengelolaan lembaga pendidikan anak usia dini ditentukan oleh aspek-aspek pengelolaan seperti kurikulum, infrastruktur, pemasaran, peserta didik, supervisi dan pendidik. Salah satu manajemen terpenting adalah manajemen yang mengatur tentang tenaga kependidikan karena manajemen ini menentukan bagaimana pendidik memberikan fasilitas untuk mengembangkan kemampuan yang dimiliki oleh anak sehingga dapat mencapai tujuan pendidikan yang diharapkan. Penelitian ini bertujuan untuk meningkatkan Manajemen PAUD (Pendidikan Anak Usia Dini) dengan mengidentifikasi permasalahan institusi. Penelitian ini menggunakan model penelitian deskriptif kualitatif. Sampel penelitian adalah guru di TK AULIA Surakarta. Hasil penelitian menunjukkan bahwa pengamatan, perhatian, komunikasi, kepribadian guru dengan anak telaksana dengan baik serta guru selalu melakukan konsultasi permasalahan anak menunjukkan rata-rata guru taman kanak-kanak AULIA Surakarta sudah melaksanakan tugasnya dengan baik.
\end{abstract}

Kata Kunci: identifikasi; manajemen paud; kualitas institusi

Copyright (c) 2021 Upik Elok Endang Rasmani, Warananingtyas Palupi, Jumiatmoko, Nurul Shofiatin Zuhro, Anjar Fitrianingtyas $\triangle$ Corresponding author:

Email Address : upikelok@staff.uns.ac.id (Jl. Slamet Riyadi No. 449, Laweyan, Surakarta)

Received 9 November 2021, Accepted 10 Januari 2021, Published 9 May 2021 


\section{INTRODUCTION}

Early childhood is one of the critical stages of development, this is evidenced by the development of children carried out continuously and continuously which affects the next stage of child development. Children can be said to have successfully completed their developmental tasks if the child can meet every demand for the child's age development (Margaretha Sri Y, 2012). A child is said to be successful in the future if the child gets full service to fulfill his or her age goals from the age of 0-6 years. Whereas for children who have not maximally fulfilled their life development goals, this can be influenced by inadequate educational services and difficulties in developing their lives.

The Chair of the Indonesian ECE Educators Association stated stated that many problems prevented the creation of quality Institutions (Sihaloho, 2016). Some of the main problems include: (1) Teachers with a basic degree in Early Childhood Education or Psychology are only $23.06 \%$, and they are the key to achieving a high standard. Furthermore, their educational level is one of the primary indicators of quality in (Gilliam \& Marchesseault, 2005), (2) The low-quality Early Childhood Education programs and institutions (Cacciola \& Downs, 2013), (3) low family involvement in the program (Rosita, 2019), (4) The tendency to focus on tutorials in Early Childhood Education leads to academic nuances (Daneri, 2018), 5) low educational investment at the its level (Ho \& Lee, 2016) ; (6) High nutritional problems and early childhood development (McCoy et al., 2018), and (7) The status of the teacher in the non-formal institutions has not been recognized (Nurhasanah R \& DWIYAMA, 2019).

Early childhood education teacher competencies and companions as described in Circular number 26 of 2007 and Circular number 58 of 2009 include pedagogical competence, personality competence, social competence and professional competence. Meanwhile, still in Circular number 58 of 2009, it is also explained about the competence to manage early childhood education, namely understanding the basics of care, skilled in carrying out parenting, behaving and behaving according to children's psychological needs.

All of the above problems mean that its management is for the creation of high-quality design. Management is a process of planning (Rasmani et al., 2020), Organizing, Actuating, and controlling pillars of resources to achieve goals effectively and efficiently (Griffin, 2004). The realization of the Indonesian gold generation in 2045 is the goal of the nation which can be achieved by participating in high-quality Early Childhood Education programs. The first pillar in improving its management is planning by design and evidence (Nakajima et al., 2019).

The management of education personnel (Mustari, 2014: 213) is an activity which includes the establishment of norms, standards, procedures, appointments, guidance, management, welfare and dismissal of school education personnel in order to carry out their duties and functions in achieving school goals. The management of teaching and education personnel (Rugaiyah 2010: 99) is activities to manage personal education in carrying out tasks accordingly duties and functions in order to run effectively.

The main source for the composition of planning pillar in this research, is to provide comprehensive studies in the form of documentation and mapping of global issues related to the management of Early Childhood Education, which is based on benchmarking and forecasting (Terry, 2010). Benchmarking is a process whereby management objects that need to be carefully evaluated are documented for proper decisions making (Garengo, 2019). Meanwhile, Forecasting is explained as a prediction of the state of an object in the future. Ideally, both need to be conducted simultaneously.

The research to map the global problems in the country with their various arguments has not been conducted in a comprehensive, in-depth, and sustainable manner. Most management research in PAUD focuses on the implementation of management for certain components in PAUD, such as institutions, students, human resources, learning, and so on (Ita, 2018). The Early Childhood Education management studies have not specifically examined the basic material of the first pillar of its process, which includes the planning pillar (Chan, 2018). 
The analysis of Early Childhood Education management facilitates the preparation of good planning pillars. This is because good planning need to answer six (6) main questions which include (1) What actions should be taken, (2) Why it needs to be performed, (3) Where it was performed (4) When the action was conducted, (5) performer of these actions; and (6) How to conduct these actions (Terry, 2010). The government is facing several problems related to the development of Early Childhood Education program.

In addition to funding problems, there are still various issues faced by the government. Which includes, Firstly, the lack of community understanding of the importance of Early Childhood Education for the subsequent child development. Secondly, not all regions have apparatus that specifically handles the Early Childhood Education development at the operational level. Thirdly, there is still a lack of educational field staff in early childhood. Meanwhile, there is a great deal of unemployment in education, and also there is still very few qualified staff as Early Childhood Education educators. Fourth, the vast service and difficult to reach the area due to geographic restrictions are often the main causes of information lagging and inaccessible services.

Based on the various descriptions stated above, several problems that educational institutions face in improving the quality of learning can be identified. The impact of these problems is used as a benchmark for the progress of an institution that organizes Early Childhood Education (Chapman et al., 2017). The learning process is inseparable from the good management of the organization. Therefore, the research raises the question of the management of early childhood programs.

Today, many institutions that conducts Early Childhood Education program only last for 1 to 2 years. This is due to funding problems, and lack of coordination between the institution and the surrounding community. The case also occurred in the AULIA Kindergarten in Surakarta, Laweyan sub-district. Large number of institutions closed due to the lack of funds, and their lack of knowledge in managing Early Childhood Education therefore, the educators and educational staff in the institution are unable to work professionally.

In the context of the above, this study focuses on identifying the management of Early Childhood Education to improve the quality of its facilities. The research problem was described using the following questions: How does management manage educators and teaching staff to improve the quality of learning in AULIA kindergarten Surakarta? The general objective of this study is to improve the quality of learning among Kindergarten AULIA Surakarta through management identification and socialization in Kindergarten AULIA Surakarta. Based on the general objectives above, the specific objectives of this study are to improve the management of educators and education personnel in Kindergarten AULIA in improving the quality of learning in the classroom.

\section{METHODS}

This research was conducted using descriptive qualitative methods, with the aim of describing and finding in detail the problems of PAUD management as seen from the aspects of the management of educators and educational personnel (Creswell, 2016). This research was conducted in AULIA Kindergarten, Surakarta City. The problems of an institution can be identified through the relationship between teachers and children, the relationship between schools and parents, and the relationship between teachers and peers. The data collection technique was carried out by using the method of observation and structured interviews. Structured interviews were conducted online via Google Form by considering the effectiveness of time, place and cost without reducing the substance of the data. The resource persons consisted of the principal $(P)(n=1)$, the class play group teacher $(G K K B)(n=2)$, the teacher group $A(G K A)(n=3)$, the teacher group $B(G K B)(n=3)$. Another technique used in data collection, apart from interviews, is observation which is carried out on the official 
website of the institution to see how the management process is carried out in AULIA Kindergarten, Surakarta and through zoom meetings with teachers and school principals.

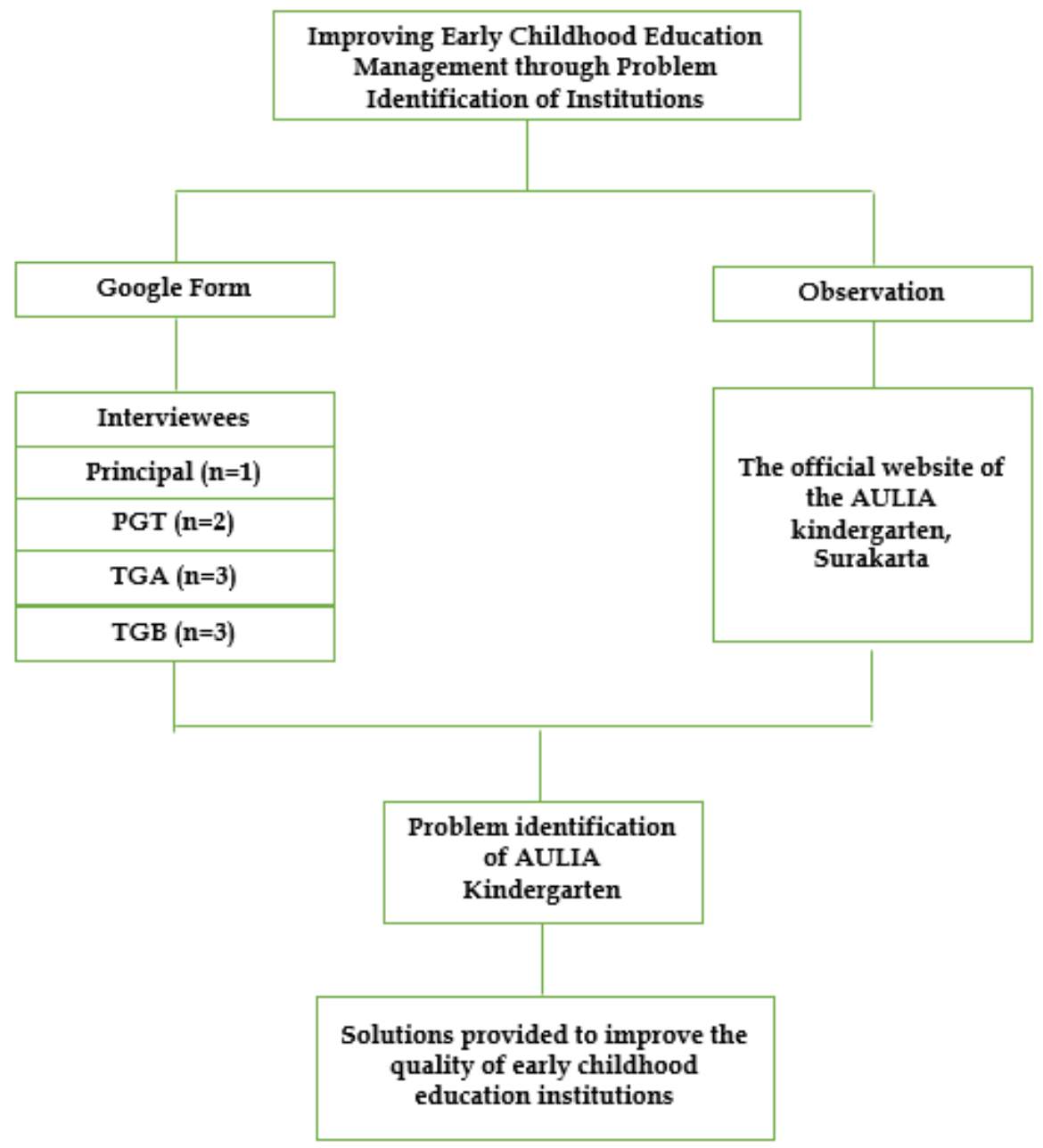

Picture 1. Stage of research data analysis

\section{RESULTS AND DISCUSSION}

The management of educators and education personnel is one important aspect that influences the management of early childhood education, whether it is successful or not. Management educators and education discuss how human resources are processed to carry out work from the start of entry, into an institution to human resource development for the advancement of educational institutions (Djafri et al., 2020). Erni Munastiwi (2019) in her book Management of Early Childhood Education Institutions for Beginners said that there needs to be attention to management aspects by applying moral principles to teachers so that teachers are motivated to make new innovations in the implementation of education and be more enthusiastic in improving their performance.

The research carried out at AULIA Kindergarten Surakarta has the aim of identifying educational problems through the implementation of the management of educators and education personnel at the institution. The management of educators and education personnel can be said to be successful if there are basic principles in implementation that are firmly upheld and carried out by institutions such as competent human resources, good management of human resources, a culture and organizational atmosphere that pays more attention to managerial attitudes, teamwork and coordination between members of educators as well as competency development in improving the quality of early childhood education institutions.

The results of research in the form of institutional observations through the school's official website obtained data in the form of 9 teachers with undergraduate qualifications 
majoring in early childhood education in AULIA Kindergarten, Surakarta, and 2 teachers with non-early childhood education. The average age of teachers in AULIA Kindergarten Surakarta is 40 years old and several times have attended training related to early childhood education. The results of interviews with educators at AULIA Kindergarten Surakarta, it was found that the training or workshops that had been attended included training on making learning implementation plans, 2013 curriculum training, child development training, nutrition training in early childhood. This training is followed in turn by the teacher, so that every training that is held, not all teachers can participate in the training.

The results of filling in the g-form are indicated by the questions given by the researcher to the teacher, consisting of teachers' observations on children's development; teacher's attention to children; teacher communication with children; teacher's personality in dealing with children; consultation with the principal regarding problems experienced by teachers in the classroom; implementation of learning models in the classroom; knowing the child's personality, shows that the average AULIA Surakarta kindergarten teacher has done their job well.

The teacher routinely makes reports on the results of the child's growth and development every month in stages consisting of activities carried out by the child from the time the child comes to school until the child returns from school. This is done to observe the development of children and to find out the level of development and growth experienced by children, which consists of six aspects of child development, starting from aspects of the development of moral religious values, cognitive, language, social emotional, physical motoric, and art (Alwi \& Dkk, 2018). This observation is carried out by the teacher so that the teacher can provide stimulation that can improve child development.

AULIA Kindergarten teacher, Surakarta, routinely gives children attention which is shown through love for children. The attention given by the teacher is manifested as a form of manifestation of parents who love their children. With the attention given by the teacher to the child, the child will be more enthusiastic in participating in learning and the quality of learning in the classroom will also increase. In addition, the existence of a form of attention given by the teacher to the child will make the child feel cared for and respond to himself being appreciated (Lisnawati, 2018). In addition, the teacher also often communicates with the child so that the child feels comfortable talking, playing and joking with the teacher and it is not implanted in the child that the teacher is someone who is frightening and dangerous to the child. With the communication carried out by the teacher with the child, it will make the child feel comfortable in telling stories and comfortable in participating in class learning with the teacher (States et al., 2018).

The success of a learning process is shown by the teacher's efforts in knowing the child's personality and character first, because in carrying out learning the teacher needs to adjust the character and personality of the child so that what is taught by the teacher can be optimally accepted by the child, because each child has a different character- different from one another. In this case the teacher also plays an active role in shaping the personality of the child at school. Teachers also need to be patient and skilled in dealing with any differences in children's character, so that children feel comfortable with the teacher's personality (Billingham \& Billingham, 2019).

The results also showed that teachers also often consulted with school principals and other teachers regarding problems experienced in the classroom. This consultation is carried out with the aim of finding a solution to the problems experienced related to the professionalism of a teacher and also as a way to share opinions and solutions so that teachers can exchange knowledge and gain insight. In addition, school principals also often send teacher representatives to attend trainings, webinars and workshops related to early childhood education so that teachers can complement and share information related to the implementation of early childhood education, especially in AULIA Kindergarten, Surakarta. 
Leadership carried out by the principal is based on the Serve concept or the concept of serving conveyed by Ken Blancard and Mark Miller in Syamsul Kuniawan, where the principal gives a service attitude to colleagues in work based on the leadership attitude he has and has high motivation in implementing management in the institution where he serves. The following is a diagram of the Serve concept or serving concept conveyed by Ken Blancard and Mark Miller in Syamsul Kuniawan (2016):

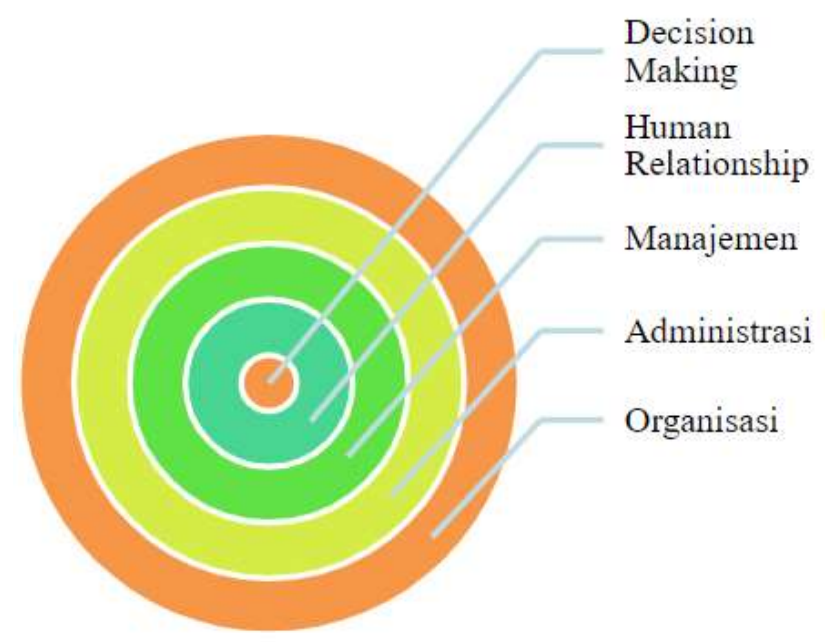

Picture 2. Concept of Leadership Management for Educators and Education Personnel

The implementation of learning in the classroom is also closely related to the learning model applied. The teacher always tries to provide innovative attractive learning models for children, so that children are more active in participating in learning (Amri, 2010). The learning model applied in AULIA Kindergarten, Surakarta, is in the form of area and group models with safety. This is due to the lack of space and lack of education personnel who master certain fields when applying the center learning model. However, school principals and teachers are still trying to apply interesting learning models so as to create a comfortable, safe, cheerful and fun classroom atmosphere for children.

Based on the results of the above research, the researcher provides advice to schools in an effort to improve the management of educational institutions for this age, especially the management of education personnel in AULIA Surakarta Kindergarten, namely by providing references to interesting activities, in increasing the competence of teachers, through providing information related to training activities and webinars that teachers can participate in. So that the abilities possessed by teachers are increasing. In addition, researchers also provide assistance to teachers and principals regarding the implementation of classroom learning and the preparation of effective and efficient and innovative learning plans for classroom teacher learning, so as to create a pleasant classroom atmosphere for children.

\section{CONCLUSION}

The management of early childhood education institutions, especially the management of education personnel at AULIA Kindergarten, Surakarta, has been carried out well. commu; there is regular communication between the teacher and the principal as well as with other teachers. However, there is a need for an increase in the quality of teacher management, namely increasing the ability of teachers through training and webinars and workshops as well as providing assistance in formulating attractive, innovative and efficient learning designs.

\section{ACKNOWLEDGEMENT}

We are tremendously gratefull to all teachers and staff of Kindergarten Aulia Surakarta and also for all of the research team and students involved in helping this research. 


\section{REFERENCES}

Alwi, B. M., \& Dkk. (2018). Manajemen Peserta Didik Pada Taman Pendidikan Anak Usia Dini Do'a Ibu. Indonesian Jural of Early Childhood Education, 1(1), 53-62. https://doi.org/10.24252/nananeke.v1i1.6906

Amri, A. (2010). Proses Pembelajaran Inovatif dan Kreatif dalam Kelas. Prestasi Pustakaraya. Billingham, K. A., \& Billingham, K. A. (2019). Early Childhood Development. In Developmental Psychology for the Health Care Professions (pp. 59-85). https://doi.org/10.4324/9780429045141-3

Cacciola, J., \& Downs, M. (2013). International and US styles of early childhood education. Developmental Psychology at Vanderbilt. https://my.vanderbilt.edu/developmentalpsychologyblog/2013/12/internationaland-us-styles-of-early-childhood-education/

Chan, C. W. (2018). Leading today's kindergartens: Practices of strategic leadership in Hong Kong's early childhood education. Educational Management Administration and Leadership, 46(4), 679-691. https://doi.org/10.1177/1741143217694892

Chapman, K., Dixon, A., Wilson, K., Dobbelsteyn, C., Cordero, K., Trost-Cardamone, J., Beckett, L., Helderman, L., Logdahl, E., Kuric, A., \& Baylis, A. (2017). Benchmarking speech outcomes of kindergarteners with cleft palate. Cleft Palate-Craniofacial Journal, 54(3), e43-e44. https:// www.embase.com/search/results?subaction=viewrecord\&id=L617893530\&f $\underline{\text { rom }=\text { export }}$

Creswell, J. . (2016). Research Design (Pendekatan Kualitatif, Kuantitatif, dan Mixed) Edisi 4. Pustaka Pelajar.

Daneri, M. P. (2018). Precursors and Academic Consequences of Latino Children's SelfRegulation. In ProQuest Dissertations and Theses. http://login.ezproxy1.lib.asu.edu/login?url=https://www.proquest.com/dissertatio ns-theses/precursors-academic-consequences-latinochildrens/docview/2128012291/se-2?accountid=4485\%0Ahttps:/ / arizona-asuprimo.hosted.exlibrisgroup.com/openurl/01ASU/01ASU_SP?ge

Djafri, N., Arwildayanto, A., \& Suking, A. (2020). Manajemen Kepemimpinan Inovatif pada Pendidikan Anak Usia Dini dalam Perspektif Merdeka Belajar Era New Normal. Jurnal Obsesi: Jurnal Pendidikan Anak Usia Dini, 5(2), 1441-1453. https://doi.org/10.31004/obsesi.v5i2.901

Garengo, P. (2019). Benchmarking. In Quality Management: Tools, Methods and Standards (pp. 91-107). https://doi.org/10.1108/978-1-78769-801-720191006

Gilliam, W. S., \& Marchesseault, C. M. (2005). From Capitols to Classrooms, Policies to Practice: State-Funded Prekindergarten at the Classroom Level From Capitols to Classrooms, Policies to Practice: State-Funded Prekindergarten at the Classroom Level. Teacher.

Griffin, R. W. (2004). Manajemen (Edisi ketujuh). Erlangga.

Ho, D., \& Lee, M. (2016). Capacity building for school development: current problems and future challenges. School Leadership and Management, 36(5), 493-507. https://doi.org/10.1080/13632434.2016.1247040

Ita, E. (2018). Manajemen Pembelajaran PAUD di TK Rutosoro Kec. Golewa Kab. Ngada Flores NTT. Jurnal Dimensi Pendidikan Dan Pembelajaran, 6(1), 45-52.

Kurniawan, S. (2016). "Sekolah Progresif." Jurnal At-Turats10, 1(1). https://doi.org/10.24260/at-turats.v10i1.446

Lisnawati, I. (2018). The Professionalism of Indonesian Teachers in The Future. JETL (Journal Of Education, Teaching and Learning), 3(1), 28. https://doi.org/10.26737/jetl.v1i1.458

Margaretha Sri Y, E. (2012). Kompetensi Paedagogik Guru PAUD dalam Mengembangkan Pembelajaran untuk Anak Usia Dini. Jurnal Cakrawala Dini, 3(1). https://doi.org/10.17509/cd.v3i1.10325 
McCoy, D. C., Waldman, M., \& Fink, G. (2018). Measuring early childhood development at a global scale: Evidence from the Caregiver-Reported Early Development Instruments. Early Childhood Research Quarterly, 45, 58-68. https:// doi.org/10.1016/j.ecresq.2018.05.002

Munastiwi, E. (2019). Manajemen Lembaga PAUD Untuk Pengelola Pemula. Yogyakarta: Program Studi Pendidikan Islam Anak Usia Dini.

Nakajima, N., Hasan, A., Jung, H., Brinkman, S., Pradhan, M., \& Kinnell, A. (2019). Investing in school readiness: A comparison of different early childhood education pathways in rural Indonesia. International Journal of Educational Development, 69(September 2018), 22-38. https:// doi.org/10.1016/j.ijedudev.2019.05.009

Nurhasanah R, N. R., \& DWIYAMA, F. (2019). Pengembangan Lembaga PAUD melalui Implementasi Manajamen Berbasis Sekolah. Adaara: Jurnal Manajemen Pendidikan Islam, 8(1), 797-815. https:/ / doi.org/10.35673/ajmpi.v8i1.419

Rasmani, U. E. E., Palupi, W., Jumiatmoko, J., Zuhro, N. S., \& Fitrianingtyas, A. (2020). Indikator Perencanaan pada Manajemen Lembaga Pendidikan Anak Usia Dini Unggulan. Jurnal Obsesi: Jurnal Pendidikan Anak Usia Dini, 5(1), 431. https:// doi.org/10.31004/obsesi.v5i1.611

Rosita, F. (2019). Manajemen Kurikulum Pendidikan Anak Usia Dini Dalam Meningkatkan Kepuasan Pelanggan Studi Kasus: Taman Kanak-Kanak Hamzanwadi Pancor 2019/2020. JUPE: Jurnal Pendidikan Mandala, 4(4).

Sihaloho, M. J. (2016). Masalah PAUD di Indonesia. 2016. https://www.beritasatu.com/amp/archive/353926/ini-delapan-masalah-paud-diindonesia

States, J., Detrich, R., \& Keyworth, R. (2018). Overview of Teacher Soft Skills. The Wing Institute. https://drive.google.com/file/d/1I8ih77as7y4sD00GDg670bEAOLiMW6Q/view

Terry, G. and L. W. R. (2010). Dasar-dasar Manajemen (Cetakan kesebelas). PT. Bumi Aksara. 